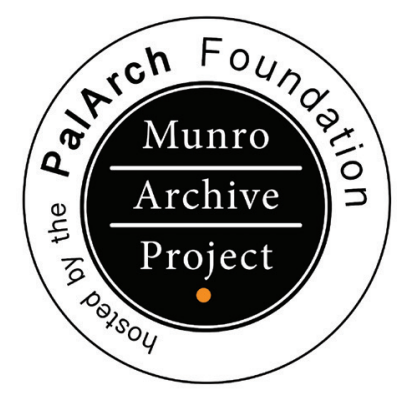

\title{
THE PLEATED DRESS OF NYWTY
}

\author{
Rosalind Janssen ${ }^{\#}$
}

*UCL Institute of Education, r.janssen@ucl.ac.uk

Janssen, Rosalind. The Pleated Dress of Nywty. - Palarch's Journal of Archaeology of Egypt/Egyptology 17(1) (2020), 1-11. ISSN 1567-214X. 11 pages +4 figures.

Keywords: Nywty, pleated garment, Saqqara

\section{Abstract}

A description of a fragment of a pleated dress, discovered in situ in 1982 by the late Peter Munro and his team in the tomb of Nywty. An evaluation of its importance for our understanding of pleated dresses in ancient Egypt. 


\section{INTRODUCTION}

It was in 1984, that I started to engage in two years of correspondence with the late Professor Peter Munro regarding his announcement in the pages of Göttinger Miszellen of the discovery of the pleated dress of Nywty (Munro, 1983: 102-103). Together with my then future husband, I visited Professor Munro at his home in Hannover, and over dinner he suggested that I write a chapter to be included in one of his final volumes. That evening is still fresh in my memory, with Professor Munro exuding the greatest enthusiasm for his Scottish ancestry. By contrast, the reasons why the proposed chapter itself never saw the light of day remain shrouded in the mists of time. I merely afforded it brief mentions in three of my own publications (Hall, 1985: 243; 1986: 29, 31; Janssen \& Janssen, 1990: 34-35'1).

It was therefore a considerable surprise to be contacted by Dr. André Veldmeijer in 2017, and asked to return to the subject once again as part of a project to ensure the publication of Munro's outstanding excavation work at Saqqara. ${ }^{2}$ In taking up Veldmeijer's gauntlet to publish "the stuff [that] has been around for thousands of years", the message is that an Egyptological contribution can hopefully gain from a period of long gestation (Personal Communication A.J. Veldmeijer, 31 May 2019). While it has taken thirty-five years, the caveat is that I can now draw on the discoveries and contributions of other scholars in relation to pleated dresses and their non-pleated counterparts. Moreover, it is entirely fitting to dedicate this contribution to the memory of the late Professor Munro at a time when the cries for the independence of his beloved Scotland grow increasingly stronger.

\section{Primary Sources}

The present work primarily relies on an unpublished manuscript by Renate Striemer, accompanied by nineteen colour photographs of Nywty's dress and scarf taken at Saqqara (Holzhäuer \& Striemer, Unpublished Manuscript). In addition, there are twenty-two $35 \mathrm{~mm}$. colour slides by Eberhard Holzhäuer, of both these textiles, ${ }^{3}$ as well as nine black and white photographs. ${ }^{4}$ Text, photographs and slides were taken in the 1980s and represent key sources for the present study.

\section{Nywty's Dress and Pleated Fragments: Description}

The linen dress was discovered in 1982 lying directly on the body of Nywty in room C5/9A (Munro, 1983: 102; figure 1), ${ }^{5}$ in a complex of buildings that is dated to the late First Intermediate Period or, more likely, the Eleventh Dynasty (Munro, 1983: 105). It is in a very fragmentary and stained condition (figure 2). Its edges are dark brown and brittle with lighter patches nearer to the centre as a result of contact with the embalming fluids. Notwithstanding, sufficient survives of the front portion to reveal it as a horizontally pleated garment comprising three pieces of material: the left and right side of the bodice, and a skirt section.

The horizontally pleated bodice (figure 3A) is now fragmentary, but its narrow cut confirms its owner as a very young, slender female. ${ }^{6}$ Well-preserved is the $\mathrm{V}$-shaped opening at the centre front (figure 3B). Normally on such dresses one of its edges would be fringed, but here both are selvedged. ${ }^{7}$ Knotted in are two corresponding pairs of ties, each approximately 11 centimetres in length, which

$1 \quad$ Repeated in Janssen \& Janssen (2007: 30-31).

2 Munro Archive Project (MAP), which will be available on the internet in spring 2020

3 These excavation notes can be viewed on the aforementioned website of the MAP.

4 Unfortunately, most of the colour photographs and slides are of inadequate quality to include in the present work.

5 On the system of numbering of the constructions within the concession, see Munro (1993: 4-6).

6 The young age of the female was also inferred from the anthropological investigation by Dr. Helmut Kartscher (Munro, 1983: 103).

$7 \quad$ For a glossary of textile terminology, see Vogelsang-Eastwood (1993: xvii-xxii). 


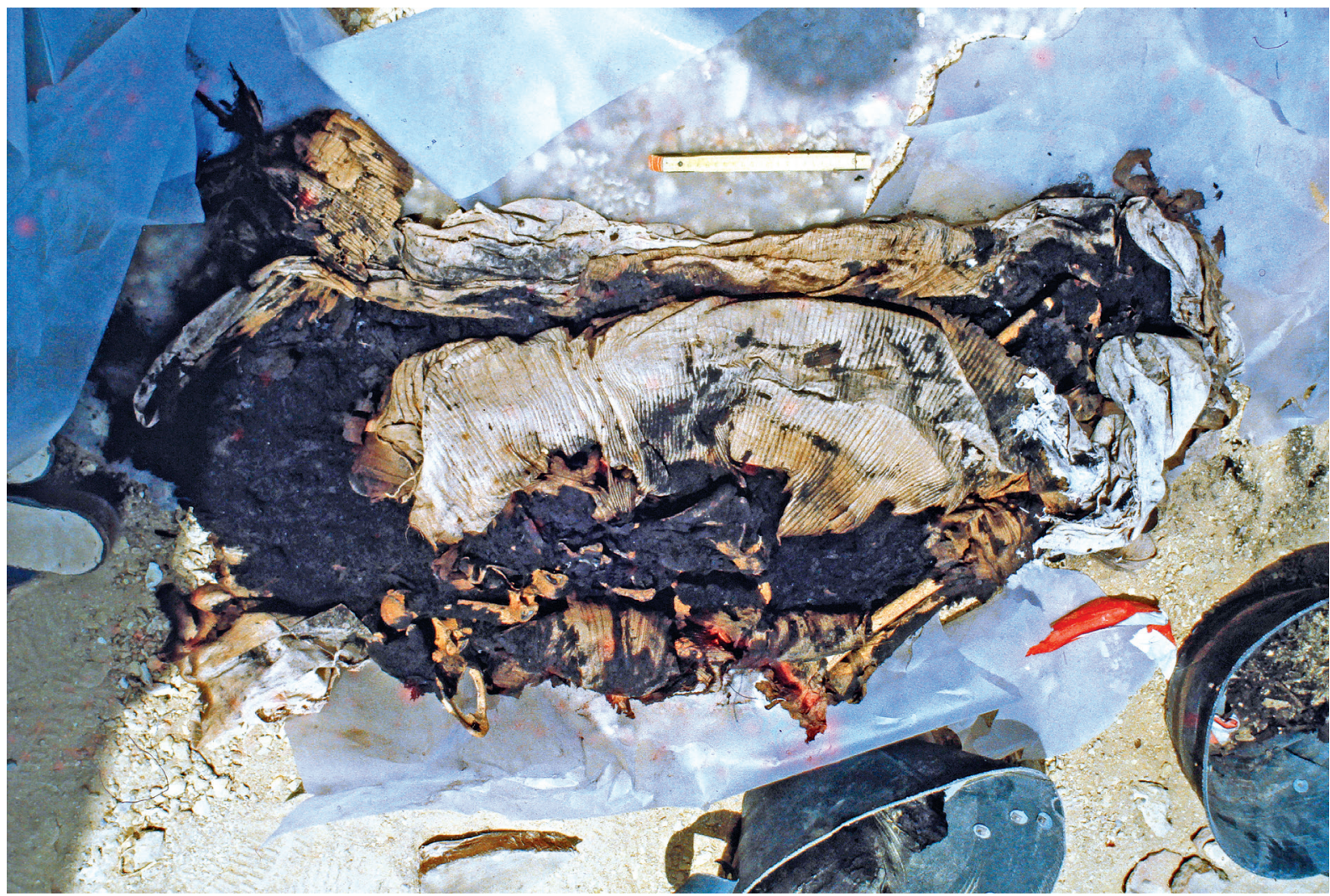

Figure 1. The dress on the body after the mummy wrappings have been partially removed. (C) MAP. were used to close the neckline. Formed of plied yarn, all four are securely knotted at their free ends. The bodice has been attached to the top of the main body of the dress by means of a run and fell seam ${ }^{8}$ (arrow in figure 3B). This utilises 2.5 centimetres of extra fabric, and is secured by sixteen whipping stitches per 10 centimetres. Since each yoke or half section misses its sides, there is no indication that the bodice once extended into the anticipated long sleeves.

The skirt measures 103 centimetres in length from top to hem. As is normal with such pleated garments, it evidences a central vertical crease as a result of the folding over of the cloth prior to the pleating process. The subsequent unfolding resulted in upward opening pleats on the left half of the garment, with corresponding downward opening pleats on its right hand side (figure 3D). The width measurement from the central crease to the remains of a selvedge side seam at the bottom of the dress is 30.5 centimetres, resulting in 61 centimetres in total for the front. This selvedge side seam, into which the pleats would originally have been stitched, comprises a run and fell seam utilising 1 centimetre of extra fabric, which is secured by whipping (overhand) stitches. There is no surviving trace of the normal decorative fringe. However, the side seam provides crucial evidence that Nywty's dress was once complete, for attached to the run and fell seam are the fragmentary remains of part of the back of the garment. This contradicts Munro's initial assertion that this was a 'half-dress' (Munro, 1983: 102). Instead, the skirt as one rectangle, joined selvedge to selvedge, would have measured 122 centimetres in circumference. A rolled hem at the bottom of the dress is secured by twenty whipping stitches per 10 centimetres of fabric.

Found connected with the garment were three further pleated fragments. Made of finer linen, their pleats are narrower than those on Nywty's dress, indicating that they probably formed part of another dress. Her so-called scarf is 207 centimetres in length by 94 centimetres in width, and was not pleated. Large

8

Vogelsang-Eastwood's flat seam (1993: xviii). 


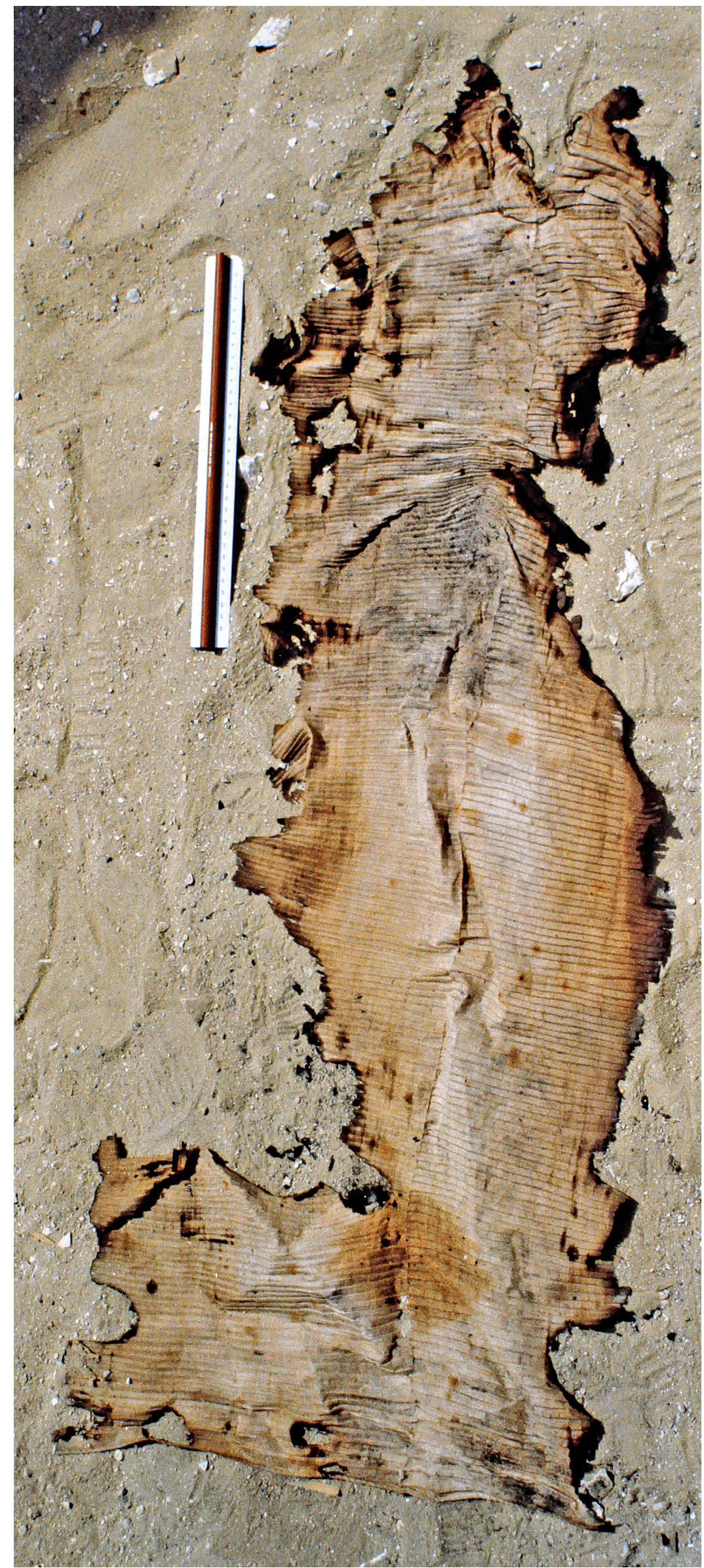

Figure 2. Full view of the dress immediately after removal from the body. (C) MAP. 

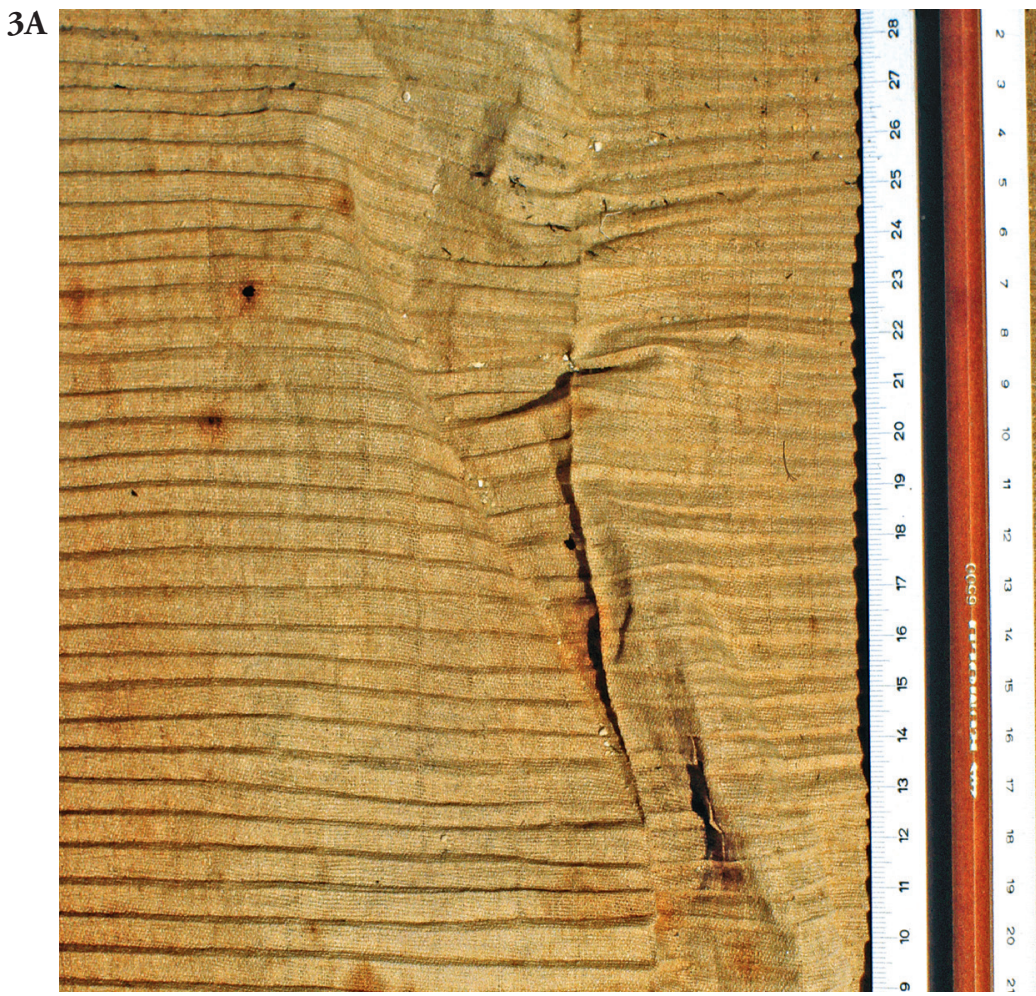

Figure 3. Details of the dress. A) The horizontal pleats; $B$ ) The well-preserved $V$-shaped opening at the centre front with corresponding ties. The arrow points to the flat seam (see diagram); $C$ ) Detail of the rolled hem at the bottom of the garment (see diagram); D) The upward and downward opening pleats. (C) MAP.
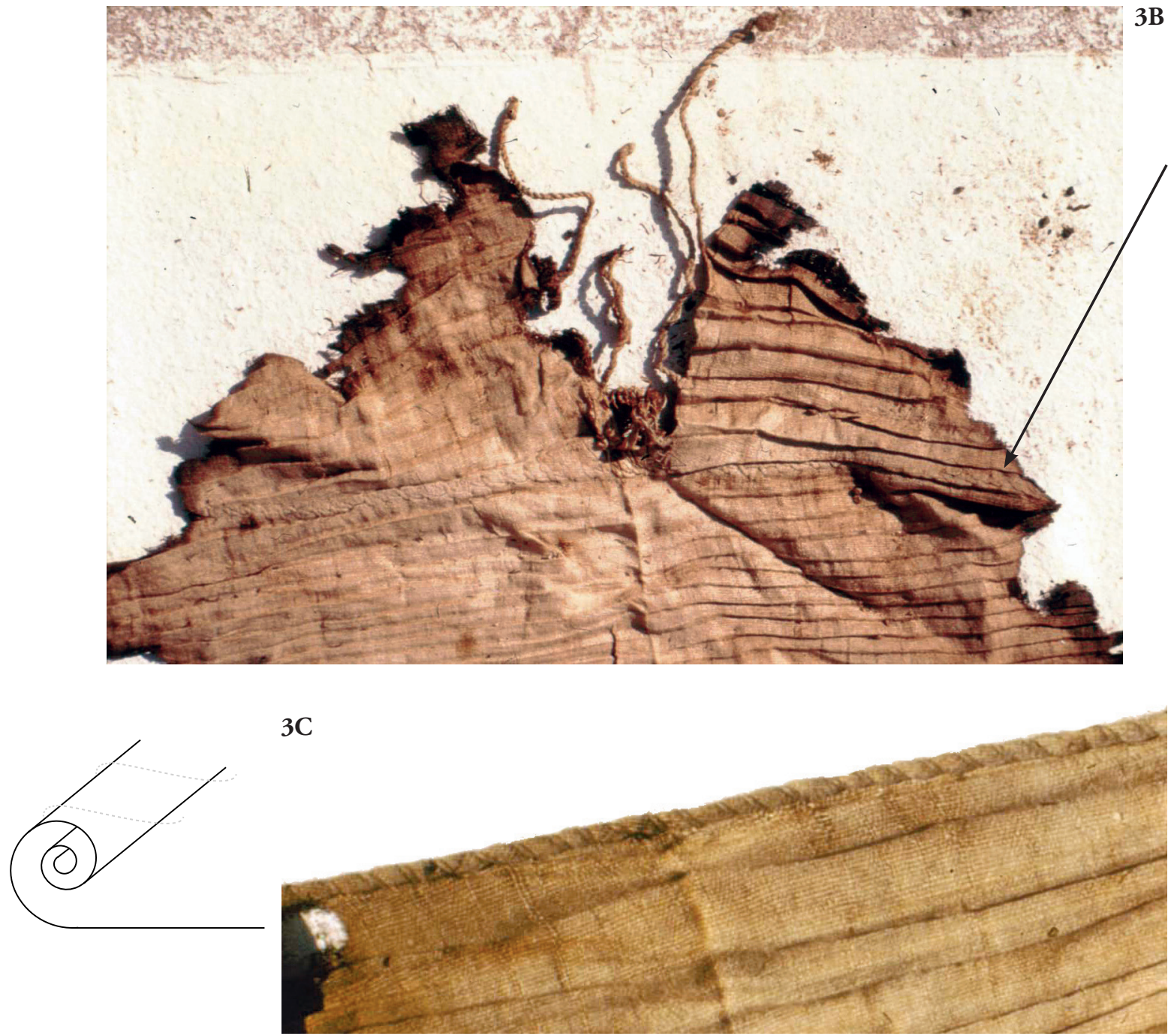

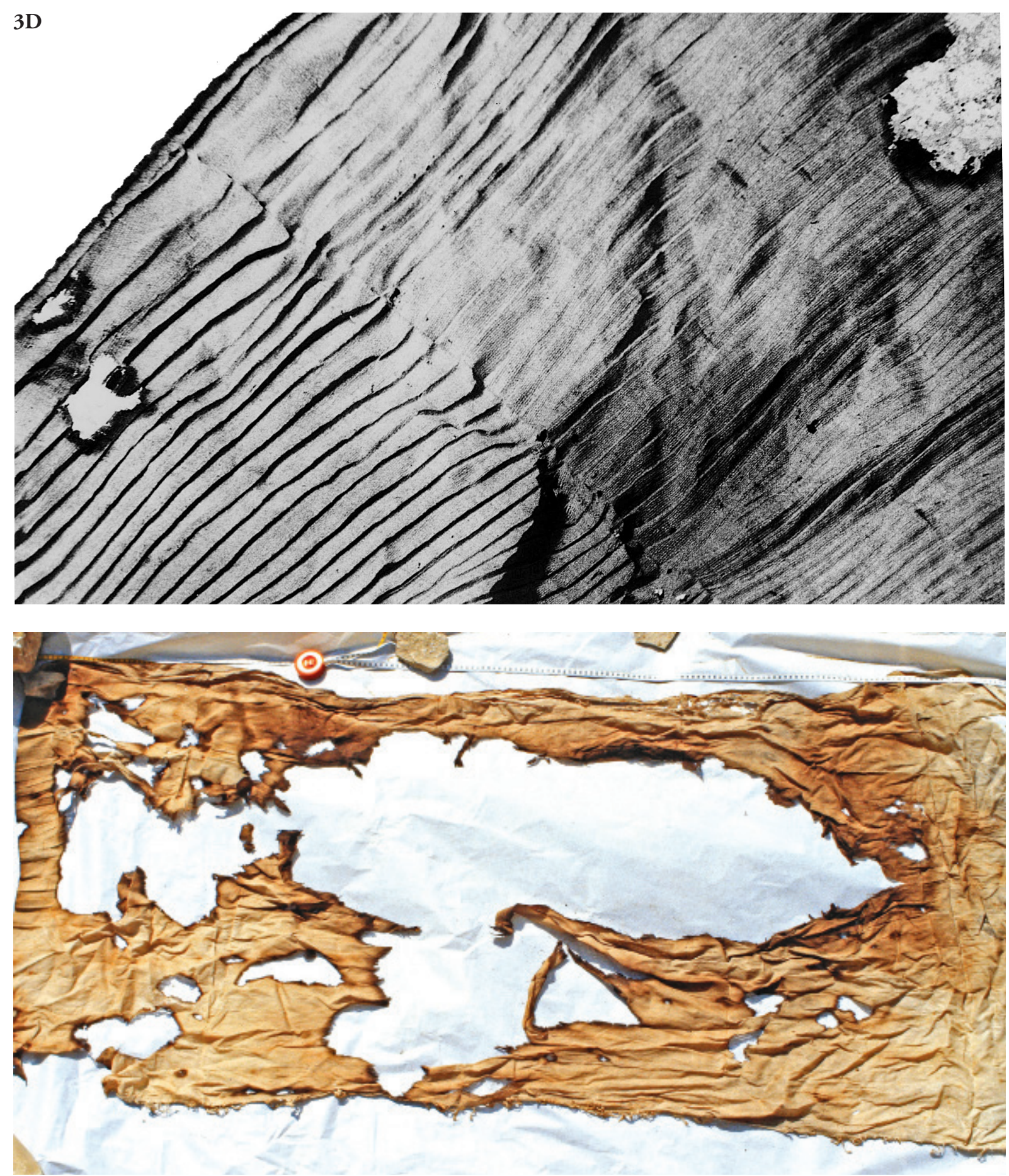

Figure 4. The remains of the large so-called scarf. () MAP.

areas are missing, and the originally white linen is now brownish in colour. Dark brown brittle areas once again imply direct contact with the embalming fluids from the mummy. One of the long edges still exhibits 6 centimetres of woven-in fringes, while the opposing edge is selvedged. Moreover, one of the shorter edges bears a 7-centimetre portion of its original rolled hem. A clear crease line at the best-preserved section of the scarf shows that it had originally been folded up. 


\section{Comparative Material}

While early extant garments are extremely rare, it is remarkable that approximately thirty-five parallels to Nywty's dress survive today. All display horizontal pleating to both the bodice and skirt of the garment, and date from either the Sixth or the Eleventh Dynasties. While excluded from the current corpus directly below, the earlier Tarkhan and Deshasheh dresses are referenced in the ensuing discussion.

NAGA-ED-DÊR

Tomb N94 - Sixth Dynasty

Adult Female burial accompanied by a total of twelve similar dresses (Reisner, 1932: 11-13).

Cairo JE 88144 (Laurent-Täckholm, 1951: 255)

Boston 34.56a (Riefstahl, 1944: 8, Fig. 7)

Boston 34.56b

Boston 34.56c

Boston 34.56d

Boston 13.3966.A

Boston 13.3966.B

Boston 13.3966.C

Boston 136048

Boston 136049

Boston 136050

[Boston Untraced]

Tomb N110 - Sixth Dynasty

Adult female burial.

Cairo JE 88145

\section{GEBELEIN}

Unnumbered Tomb - Sixth Dynasty

Unsexed burial.

Turin S. 14087 (Hall \& Pedrini, 1984: 136-139, Pls. XXII-XXIII, Fig. 1)

Turin S. 16807

Turin S. 16792

Turin S. 16788

Turin Museo di Antropologia S.16747

\section{ASYUT}

Tomb 13 - Eleventh Dynasty

Unsexed burial, with 'plusieurs' identical garments, but only one salvageable.

Louvre E 12026 (Hall, 1985: 235-238; Chassinat \& Palanque, 1911: 162-164, Pl. XXXIII)

Turin S. 7932/4

Turin S. $7932 / 5$

Turin S. 14396 (3 pleated tunics, one still worn by the coffined mummy) 


\section{GEBELEIN OR ASYUT}

Turin S. 17127

Turin S. 17128

Turin S. 17129

Turin S. 17130

EL-HAWAWISH

Adult female burial with two folded dresses laid over her legs - late Sixth Dynasty (McFarlane, 1991)

Based on the many fragments of pleated linen, Ann McFarlane suggests that similar dresses formed part of other female graves at the site (McFarlane, 1991: 75).

Cairo Inv. Nos. unknown

\section{ELEPHANTINE}

Jana Jones (2014: 213) references "a number of unpublished, pleated dresses from the German Archaeological Institute (DAIK) excavations of the Old Kingdom burials, $[\ldots]$ stored in the magazine at the site."

MEIR

Unnumbered plundered Tomb - Eleventh Dynasty

Unsexed burial.

Cairo JE 43684 (Kamal, 1914: 171-172, Fig. 21; Spiegelberg, 1927: 154-156, Pl. 1)

Cairo Unregistered

\section{UNKNOWN PROVENANCE}

Lyon MT 46841

\section{SignificanCE OF NywTY's Dress}

There are five reasons why Nywty's pleated dress can be viewed as significant in terms of building up a history of this particular fashion style. They reside in its geographical location and archaeological context, and in the fact that it is a rare child's garment which exhibits run and fell seams, and is moreover inside-out.

Firstly, in terms of geographical location, the discovery is significant since Saqqara was "the primary burial site for the highest ranked elite" (Jones, 2014: 229). It is not surprising that we should find evidence for an extant pleated dress here, since Jones has convincingly demonstrated how the style - thereby enjoying a one thousand year usage - developed from Early Dynastic reliefs at Helwan, the second main necropolis serving the city of Memphis (Jones, 2014). It further means that we can now extend the distribution of such dresses from Elephantine in the South as far North as Saqqara. This means that discoveries of these garments are no longer centred on Middle Egyptian provincial cemeteries and the low status burials of anonymous females. A previous statement that these dresses "appear to be indicative of a purely local fashion dictated by the adverse cold of the winters in these regions" is now rendered obsolete (Hall \& Barnett, 1985: 18). Instead, this dress style was a feature of the burial of a named child at the Memphite capital, and was a popular fashion adopted all over Egypt. 
Secondly, in terms of archaeological context, the prominent positioning of the openly laid out dress on Nywty's body is significant. Where known, such dresses were normally first folded up in packets and then laid on the body. For example, McFarlane reports that at El-Hawawish, "the two dresses had been folded and laid over the legs of her [the adult female's] poorly mummified body" (McFarlane, 1991: 75). Similarly, Flinders Petrie discovered the nine Deshasheh dresses, nonpleated and of a Fifth Dynasty date, as folded up garments piled directly on top of the female burial (Hall, 1981; Petrie, 1898: 16; 31-32, Pl. XXXV).

Notwithstanding, there are three notable exceptions to the rule. Elizabeth Riefstahl and Suzanne Chaplain reveal that the adult female body in Tomb N94 at Naga-ed-Dêr was clothed in one of the twelve pleated dresses deposited in her coffin (Riefstahl \& Chapman, 1970: 244). More recently, Borla and Oliva have published photographs of two Turin mummies, excavated respectively at Asyut and Gebelein, which are still wearing pleated dresses (S.14396 and S.16747; Borla \& Oliva, 2015).

Of tangential relevance is an earlier Fourth Dynasty burial of an adult female, discovered by Reisner in Mastaba G2220B at Gizas Western Cemetery and now also in the Boston Museum (Boston 33.4-22a; Hall, 1986: 29-30, Fig. 19; Reisner, 1942: 452-453, Pl. 42). She was similarly clothed in a sleeveless, albeit nonpleated, shift dress. This was unfortunately destroyed during the examination of the mummy. Based on the evidence of Nywty's dress having been once complete, my earlier identification of the Giza woman as wearing only the front half of a garment is now rendered far from certain (Hall, 1985: 243). Indeed, Jones was rightly cautious in stating that 'neither the excavation photograph nor the report clarifies whether the garment was simply a "cut-out" laid over the body, or an entire dress" (Jones, 2014: 217-218).

Thirdly, Nywty's dress is important in terms of the age of the wearer. Surviving children's garments are extremely rare, and this is the only pleated dress belonging to a juvenile. The closest parallel in this regard is the considerably earlier child's dress from Tarkhan now in UCL's Petrie Museum (UC. 28614B1; Hall \& Adams, 1979; Landi \& Hall, 1979). Radiocarbon dating, carried out in 2015 at the University of Oxford's radiocarbon unit, suggests that it may even pre-date the First Dynasty (Stevenson \& Dee, 2016: http://www.antiquity.ac.uk/projgall/ stevenson349). However, while this dress is similarly cut and tailored, it only exhibits pleating on the bodice, and not on the skirt.

The fourth reason for the importance of Nywty's dress lies in its run and fell seams at the bodice and skirt. The replacement of the habitual rolled and whipped seams with far stronger seams, can be viewed as a deliberate attempt on the part of the dressmaker to create a pleated dress designed for its owner. As today, run and fell seams are particularly suited to children's clothes subject to excessive wear and washing. The appearance of such seams on four children's sleeves from New Kingdom Gurob was noted by this author previously: the pair in the Petrie Museum, and the two unrelated sleeves in the Manchester Museum (UC. 8980A; Hall, 1980: 29-38, pl. 1). With Nywty's dress, run and fell seams can be taken back in time to the Eleventh Dynasty.

A noteworthy characteristic of the child's dress from Tarkhan is that it was worn in life, and then deposited in the tomb inside-out as if pulled off over the head. This brings us to the fifth and perhaps most important point of significance in relation to Nywty's dress. The evidence from Holzhäuer's detailed photographs, combined with Striemer's repeated descriptions of a 'rolled-in hem towards the neck', reveals that it too is inside-out (Holzhäuer \& Striemer, Unpublished: 6-7. See Manchester 494 and 495; Janssen \& Hall, 1981). This necessitates a revision of the 1985 inventory, where the present author erroneously placed it under the 
category: "Unworn Dresses especially made for a Funerary Context and therefore right-side out" (Hall, 1985: 243). As with the Tarkhan, Naga-ed-Dêr, and Asyut garments, there is every indication that Nywty's dress was a made-to-measure dress that was worn by her during life (Hall, 1985: 238). Reference has already been made to the narrow cut of the bodice. Laundered, pleated, and then stored inside-out, the inverted dress, its finer companion, and the so-called scarf, would then have been transported directly to the tomb (Hall, 1985: 239). An interesting parallel is the inside-out dress worn by the mummy in the Museo di Antropologia (S. 16747; Borla \& Oliva, 2015, Fig. 14 on p. 120; p. 130).

Ultimately, Nywty's dress extends our knowledge of pleated garments by taking us into the realm of ancient Egyptian childhood. It provides the missing organic evidence that Middle Kingdom prepubescent children wore the same type of clothes as their elders, a feature already confirmed by reliefs, paintings, and statuary (Janssen \& Janssen, 1990: 26-27). But what of Nywty herself? It seems fitting to conclude this assessment of her dress with the Eighteenth Dynasty lamentation for Neferhotep's widow: 'She who was rich in linen, who loved clothes, lies in the cast-off garment of yesterday' (Davies, 1933: 41, pls. XXIV, LXI A). While there is now no doubt that the cast-off garment of yesterday lay directly on Nywty's young body, her childhood love of dressing up is left to the imagination of the reader.

\section{BiBLIOGRAPHY}

Borla, M. \& O. Cinzia. 2015. Pleated Dresses from the Museo Egizio of Turin. Study of the Technical Data of Fabrics. Preliminary Results. In: de Moor, A., C. Fluck \& P. Linscheid. Eds. Textiles, Tools and Techniques of the 1st Millennium AD from Egypt and Neighbouring Countries. Proceedings of the 8th Conference of the Research Group 'Textiles from the Nile Valley' Antwerp, 4-6 October 2013. - Tielt, Lannoo: 104-130.

Chassinant, É. \& C.H.A. 1911. Palanque. Une campagne de fouilles dans la nécropole d'Assiout. - Cairo, Institut français d'archéologie orientale (Mémoires publiés par les membres de l'Institut français d'archéologie orientale du Caire 24).

Davies, N. de Garis. 1933. The Tomb of Nefer-Hotep at Thebes. I. - New York, Metropolitan Museum of Art.

Hall, R. 1980. A Pair of Linen Sleeves from Gurob. - Göttinger Miszellen 40: 29-38.

Hall, R.M. 1981. Two Linen Dresses from the Fifth Dynasty Site of Deshasheh now in the Petrie Museum of Egyptian Archaeology, University College London. - Journal of Egyptian Archaeology 67: 168-171.

Hall, R.M. 1982. Garments in the Petrie Museum of Egyptian Archaeology. Textile History 13(1): 27-45.

Hall, R.M. 1985. "The Cast-Off Garment of Yesterday". Dresses Reversed in Life and Death. - Le Bulletin de l'Institut français d'archéologie orientale 85: 235-243.

Hall, R. 1986. Egyptian Textiles. - Aylesbury, Shire Publications, (Shire Egyptology 4).

Hall, R. \& B. Adams. 1979. New Exhibitions in the Petrie Museum of Egyptian Archaeology. Ancient Egyptian Linen Dresses. - The Museum Archaeologist 4: 9-10.

Hall, R. \& L. Pedrini. 1984. A Pleated Dress from a Sixth Dynasty Tomb at Gebelein now in the Museo Egizio, Turin. - Journal of Egyptian Archaeology 70: 136-139. 
Hall, R. \& J. Barnett. 1985. A Fifth Dynasty Funerary Dress in the Petrie Museum of Egyptian Archaeology. Its Discovery and Conservation. - Textile History 16(1): 5-22.

Holzhäuer, E. \& R. Striemer. Garment of Njwtj and Scarf out of Pit UH - East B. - Unpublished Manuscript (this will become available on the website of the project).

Janssen, J.J. \& R. Hall. 1981 (htri n) ish = "pair of sleeves"? - Göttinger Miszellen 45: 21-26.

Janssen, R.M. \& J.J. Janssen. 1990. Growing Up in Ancient Egypt. - London, Rubicon.

Janssen, R.M. \& J.J. Janssen. 2007. Growing Up and Getting Old in Ancient Egypt. - London, Golden House.

Jones, J. 2014. The Enigma of the Pleated Dress. New Insights from Early Dynastic Helwan Reliefs. - Journal of Egyptian Archaeology 100: 209-231.

Kamal, Moharram A.B. 1914. Rapport sur les fouilles de Said Bey Khachaba au Deir El-Gabraouî. - Annales du Service des Antiquités de l'Égypte 13: 171172.

Landi, S. \& R.M. Hall. 1979. The Discovery and Conservation of An Ancient Egyptian Linen Tunic. - Studies in Conservation 24(4): 142-152.

Laurent-Täckholm, V. 1951. Faraos Blomster. - Stockholm, Natur and Kultur.

McFarlane, A. 1991. A Pleated Linen Dress from El-Hawawish. - Bulletin of the Australian Centre for Egyptology 2: 75-80.

Munro, Peter, 'Der Unas-Friedhof Nord-West. Vorbericht über die Arbeiten der Gruppe Hannover/Berlin in Saqqara', GM 63 (1983), 102-103.

Munro, P. 1993. Der Unas-Friedhof Nord-West. I. Topographisch-historische Einleitung. Das Doppelgrab der Königinnen Nebet und Khenut. - Mainz, Philipp von Zabern.

Petrie, W.M.F. 1898. Deshasheh. - London, Egypt Exploration Fund.

Reisner, G.A. 1932. A Provincial Cemetery of the Pyramid Age. Naga-ed-Dêr. III. - Oxford, Oxford University Press.

Reisner, G.A. 1942. A History of the Giza Necropolis. I. - Cambridge, MA, Harvard University Press.

Riefstahl, E. 1944. Patterned Textiles in Pharaonic Egypt. - Brooklyn, Brooklyn Museum, Brooklyn Institute of Arts and Sciences.

Riefstahl, E. \& S.E. Chapman. 1970. A Note on Ancient Fashions. Four Early Egyptian Dresses in the Museum of Fine Arts, Boston. - Boston Museum Bulletin 68(354): 244-259.

Stevenson Smith, W. 1935. The Old Kingdom Linen List. - Zeitschrift für ägyptische Sprache und Altertumskunde 71: 134-139.

Spiegelberg, W. 1927. Altägyptische gefältelte (plissierte) Leinwandstoffe. - Annales du Service des Antiquités de l'Égypte 27: 154-156.

Stevenson, A. \& M.W. Dee. 2016. Confirmation of the World's Earliest Garment. The Tarkhan Dress. Antiquity Project Gallery 90(349):

http://www.antiquity.ac.uk/projgall/stevenson349.

Vogelsang-Eastwood, G. 1993. Pharaonic Egyptian Clothing. - Leiden, Brill.

Submitted: 3 January 2020

Published: 26 February 2020

(C) 2020 Janssen. This is an open-access article distributed under the terms of the Creative Commons Attribution License, which permits unrestricted use, distribution, and reproduction in any medium, provided the original author and source are credited. 